\title{
Application to Market New Drug, Biologic, or Antibiotic for Human Use
}

National Cancer Institute

\section{Source}

National Cancer Institute. Application to Market New Drug, Biologic, or Antibiotic for

Human Use. NCI Thesaurus. Code C73111.

An application submitted to a regulatory agency according to the Title 21 , Code of Federal Regulations, Parts 314 and 601 in order to seek permission to market a new pharmaceutical, or biological agent, or antibiotic for human use. 